\title{
Waste Biomass Gasification Simulation Using Aspen Plus: Performance Evaluation of Wood Chips, Sawdust and Mixed Paper Wastes
}

\author{
Sahar Safarian*, Christiaan Richter, Runar Unnthorsson \\ Faculty of Industrial Engineering, Mechanical Engineering and Computer Science, University of Iceland, \\ Reykjavik, Iceland \\ Email: *sas79@hi.is
}

How to cite this paper: Safarian, S., Richter, C. and Unnthorsson, R. (2019) Waste Biomass Gasification Simulation Using Aspen Plus: Performance Evaluation of Wood Chips, Sawdust and Mixed Paper Wastes. Journal of Power and Energy Engineering, 7, 12-30. https://doi.org/10.4236/jpee.2019.76002

Received: May 29, 2019

Accepted: June 23, 2019

Published: June 26, 2019

Copyright $\odot 2019$ by author(s) and Scientific Research Publishing Inc. This work is licensed under the Creative Commons Attribution International License (CC BY 4.0).

http://creativecommons.org/licenses/by/4.0/

cC) (i) Open Access

\begin{abstract}
Biomass is one of the most widely available energy sources and gasification is a thermal conversion process where biomass is transformed into a fuel gas with a gasifying agent. In this paper by using ASPEN Plus, a new steady state simulation model for down draft waste biomass gasification was developed. The model that is stoichiometric equilibrium-based is proposed to be used for optimization of the gasifier performance. Prediction accuracy of the model is validated by comparing with available experimental and modeling results in other literature. Then the model is used for comparative analysis of the gasification performance of sawdust, wood chips and mixed paper wastes. In the model, the operating parameters of temperature and equivalence ratio (ER) have been varied over wide range and their effect on syngas composition, syngas yield, low heating value (LHV) of syngas and cold gas efficiency (CGE) has been investigated. Raise in temperature increases the production of $\mathrm{CO}$ and $\mathrm{H}_{2}$ which leads to higher syngas yield, LHV and CGE. However, increasing ER decreases the production of $\mathrm{CO}$ and $\mathrm{H}_{2}$ which results lessens in LHV and CGE but syngas yield continuously increases because more oxygen is available for biomass reactions at high ER. The optimal values of $\mathrm{CO}$ and $\mathrm{H}_{2}$ mole fraction and CGE of sawdust, wood chips and mixed paper wastes are located at $900^{\circ} \mathrm{C}, 1000^{\circ} \mathrm{C}$ and $1000^{\circ} \mathrm{C}$, respectively and ER range is between $0.20-0.35$ regardless of the kind of biomass which is used as the feedstock.
\end{abstract}

\section{Keywords}

Waste Biomass Gasification, Simulation Model, Gasifier Performance, Waste to Energy 


\section{Introduction}

Negative impacts of fossil fuels on social, political and environmental aspects as well as energy security concerns have encouraged the interest in nonpetroleum energy sources [1] [2]. Among the various alternative energy sources, biomass has obtained more interest since it is the only suitable and renewable primary energy resource that can provide alternative transportation fuels [3] [4] [5]. Extracting energy from biomass requires biochemical or thermochemical processes [6]. During biochemical processes, biomass is converted to biogas and residual by the digestive action of living organisms. However, in thermochemical processes like gasification, biomass is converted to biofuels, gases and chemicals by applying heat and pressure. Gasification is also characterized by higher temperatures and conversion rates than biochemical and thermochemical processes, so allowing an efficient treatment of various types of biomass wastes. In addition to producing syngas from biomass for subsequent biofuel synthesis gasification typically achieves superior efficiency for electricity generation from biomass compared to more conventional alternatives like incineration. Electricity production by using gasification, extracts more electricity per kilogram biomass, or per kilogram municipal waste [7] [8] [9] [10], compared to alternatives like incineration or biogas from digesters [11].

The gasification process consists of drying, pyrolysis, combustion and gasification. Drying occurs at a temperature between $100^{\circ} \mathrm{C}-150^{\circ} \mathrm{C}$, pyrolysis is in the range of $200^{\circ} \mathrm{C}-700^{\circ} \mathrm{C}$, combustion occurs in $700^{\circ} \mathrm{C}-1500^{\circ} \mathrm{C}$ and gasification is in the range of $800^{\circ} \mathrm{C}-1100^{\circ} \mathrm{C}$ [12]. Typically, the moisture in biomass ranges from $5 \%$ to $35 \%$ that it is reduced to lower $5 \%$ during drying. In the pyrolysis step, the volatile components in the biomass are vaporized as it is heated in the absence of oxygen. The volatile vapor is a mixture of hydrogen, carbon monoxide, carbon dioxide, methane, hydrocarbon gases, tar and water vapor [13]. At the next step, oxygen supplied to the gasifier reacts with the combustible substances, resulting in $\mathrm{CO}_{2}$ and $\mathrm{H}_{2} \mathrm{O}$, which subsequently undergo reduction upon contact with the char produced from pyrolysis [12]. Reduction yields combustible gases like hydrogen, carbon monoxide and methane through a series of reactions, the main reactions in this category are in below [11] [14] [15].

In reviewing past studies, attempts in simulating biomass gasification have been carried out to evaluate the gasification performance affected by various operating conditions. The simulations of biomass gasification can be divided into kinetic rate models and thermodynamic equilibrium models. In comparison to kinetics approaches, thermodynamic equilibrium calculations have fewer complexities and independent of gasifier design, so it makes them suitable for studies on the influence of fuel process parameters [11].

The composition of a mixture at thermodynamic equilibrium can be estimated using different methods of stoichiometric and non-stoichiometric approaches. When implementing the stoichiometric method, a set of independent chemical reactions are specified, thereafter the initial concentrations of all 
chemical species are specified, and the equilibrium concentrations are then calculated by solving for the extent of every reaction. However, when implementing the non-stoichiometric method, no reactions are specified and the concentrations of the species are evaluated to minimize the Gibbs energy of the products, in accordance with the constraints imposed by the principle of conservation of mass and of the stoichiometry [16]. Numerous researchers have focused on the non-stoichiometric method for biomass gasification because for this method does not need a detailed specification of all the chemical reactions taking place in the reactor. Our recent review [11] of studies reporting the modelling of biomass gasification suggests that up to May 2018 approximately $27.5 \%$ of gasification modeling studies use the stoichiometric method, roughly $72.5 \%$ use the non-stoichiometric method and no published study uses both methods to solve the same problem. However, it is worth mentioning that the authors are not aware of any published simulation study on biomass gasification systems based on the stoichiometric method.

Hence, the objective of this study is to develop a stoichiometric steady state computer model for waste biomass gasifier using the simulation software ASPEN Plus. Then the model is applied to evaluate and compare the gasification performance of three different feedstocks; i.e., wood chips, sawdust and mixed paper waste as the significant municipal organic wastes. Finally, the effect of operating parameters like temperature and equivalence ratio (ER) on the main indicators of performance evaluation of gasification system like syngas composition, syngas yield, low heating value (LHV) of produced syngas and cold gas efficiency (CGE) are investigated to find the optimal conditions.

\section{Material and Methods}

\subsection{Simulation Model}

A new kinetic free equilibrium model based on stoichiometric approach has been developed for the downdraft air gasifier of waste biomasses by using ASPEN Plus version 10. In this study, the developed Aspen Plus model involves the following steps: specification of stream class, selection of property method, determination of the system component from databank, specification of the conventional and non-conventional components, Specifying the process flowsheet by using unit operation blocks and connecting material and energy streams, defining feed streams (flow rate, composition, and thermodynamic condition) and Specifying unit operation blocks (thermodynamic condition, chemical reactions, etc.).

\subsubsection{Assumptions}

The following assumptions are employed in the simulations of waste biomass gasification.

1) The model is at steady state, kinetic free and isothermal.

2) All gases are ideal gases, including hydrogen $\left(\mathrm{H}_{2}\right)$, carbon monoxide (CO), carbon dioxide $\left(\mathrm{CO}_{2}\right)$, steam $\left(\mathrm{H}_{2} \mathrm{O}\right)$, nitrogen $\left(\mathrm{N}_{2}\right)$ and methane $\left(\mathrm{CH}_{4}\right)$. 
3) Char contains only carbon and ash in solid phase.

4) Tar and other heavy hydrocarbons are not considered.

5) Operation at atmospheric pressure ( 1 bar).

$6)$ No heat and pressure losses occur in the gasifier.

7) Simulation is based on stoichiometric approach and by considering reactions of R1, R2, R4, R5 and R7 in Table 1.

\subsubsection{Physical Property Method}

According to our conducted review, about $30 \%$ of studies employed Peng Robinson as the physical property method for simulation of biomass gasification (Table 2). However, approximately $44 \%$ of researches have not talked about the applied physical property method. Hence in our work, Penge Robinson equation of state with Boston-Mathias alpha function (PR-BM) has been used to estimate all physical properties of the conventional components in the gasification process. This method is suitable for the nonpolar or mildly polar mixtures such as hydrocarbons and light gases and the parameter alpha in this property package is a temperature dependent variable that could be helpful for the correlation of the pure component vapor pressure when temperature is quite high. Moreover, the enthalpy and density model selected for both biomass and ash which are non-conventional components are HCOALGEN and DCOALIGT. MCINCPSD stream containing three substreams comprising MIXED, CIPSD and NCPSD class, was also used to define the structure of simulation streams for the components of biomass and ash which are not available in the standard Aspen Plus component database.

Table 1. Main gasification reactions [11] [14] [15].

\begin{tabular}{|c|c|c|}
\hline \multicolumn{3}{|c|}{ Heterogeneous reactions } \\
\hline $\mathrm{C}+\mathrm{O}_{2} \rightarrow \mathrm{CO}_{2}+394 \mathrm{~kJ} / \mathrm{mol}$ & Complete combustion & $\mathrm{R} 1$ \\
\hline $\mathrm{C}+\mathrm{H}_{2} \mathrm{O} \rightarrow \mathrm{CO}+\mathrm{H}_{2}-131 \mathrm{~kJ} / \mathrm{mol}$ & Partial combustion & $\mathrm{R} 2$ \\
\hline $\mathrm{C}+\mathrm{CO}_{2} \rightarrow 2 \mathrm{CO}-172 \mathrm{~kJ} / \mathrm{mol}$ & Boudouard & R3 \\
\hline $\mathrm{C}+\mathrm{H}_{2} \mathrm{O} \rightarrow \mathrm{CO}+\mathrm{H}_{2}-131 \mathrm{~kJ} / \mathrm{mol}$ & Water-gas & R4 \\
\hline $\mathrm{C}+2 \mathrm{H}_{2} \rightarrow \mathrm{CH}_{4}+75 \mathrm{~kJ} / \mathrm{mol}$ & Methanation & R5 \\
\hline \multicolumn{3}{|c|}{ Homogeneous reactions } \\
\hline $\mathrm{CO}+0.5 \mathrm{O}_{2} \rightarrow \mathrm{CO}_{2}+283 \mathrm{~kJ} / \mathrm{mol}$ & CO partial combustion & R6 \\
\hline $\mathrm{H}_{2}+0.5 \mathrm{O}_{2} \rightarrow \mathrm{H}_{2} \mathrm{O}+242 \mathrm{~kJ} / \mathrm{mol}$ & $\mathrm{H} 2$ combustion & R7 \\
\hline $\mathrm{CO}+\mathrm{H}_{2} \mathrm{O} \rightarrow \mathrm{CO}_{2}+\mathrm{H}_{2}+41 \mathrm{~kJ} / \mathrm{mol}$ & CO shift & R8 \\
\hline $\mathrm{CH}_{4}+\mathrm{H}_{2} \mathrm{O} \rightarrow \mathrm{CO}+3 \mathrm{H}_{2}-206 \mathrm{~kJ} / \mathrm{mol}$ & Reforming & R9 \\
\hline \multicolumn{3}{|c|}{$\mathrm{H} 2 \mathrm{~S}$ and $\mathrm{NH} 3$ formation reactions } \\
\hline $\mathrm{H}_{2}+\mathrm{S} \rightarrow \mathrm{H}_{2} \mathrm{~S}$ & $\mathrm{H} 2 \mathrm{~S}$ formation & $\mathrm{R} 10$ \\
\hline $3 \mathrm{H}_{2}+\mathrm{N}_{2} \rightarrow 2 \mathrm{NH}_{3}$ & $\mathrm{NH} 3$ formation & $\mathrm{R} 11$ \\
\hline
\end{tabular}


Table 2. Physical property methods selected by various researches.

\begin{tabular}{|c|c|c|c|c|}
\hline $\begin{array}{l}\text { Redlich Kwong Soave } \\
\text { with Boston Mathias } \\
\text { modifications } \\
\text { (RKS-BM) }\end{array}$ & $\begin{array}{l}\text { Penge Robinson } \\
\text { with Boston-Mathias } \\
\text { alpha function } \\
\text { (PR-BM) }\end{array}$ & Peng-Robinson & IDEAL & Model not mentioned \\
\hline $\begin{array}{l}\text { Paviet et al. } 2009 \\
\text { [17], Begum et al. } \\
2014 \text { [18], } \\
\text { Pardo-planaz et al. } \\
2017 \text { [19], Eikeland } \\
\text { et al. 2015 [20], } \\
\text { Eikeland and Thapa } \\
2017 \text { [21], } \\
\text { Guruprasad et al. } \\
2014 \text { [22] }\end{array}$ & $\begin{array}{l}\text { Ramzan et al. } \\
2011 \text { [23], Formica } \\
\text { et al. } 2016 \text { [6], Pala } \\
\text { et al. } 2017 \text { [24], Sun } \\
2015 \text { [25], } \\
\text { Fernandez-Lopez } \\
2017 \text { [26], } \\
\text { Xiangdong et al. } \\
2013 \text { [27] }\end{array}$ & $\begin{array}{l}\text { Kuo et al. } 2014 \\
\text { [28], Gagliano } \\
\text { et al. } 2017 \text { [29], } \\
\text { Lestinsky and } \\
\text { Palit } 2016 \text { [30], } \\
\text { Damartzis et al. } \\
2012 \text { [31] }\end{array}$ & $\begin{array}{l}\text { Han et al. } \\
2017 \text { [32] }\end{array}$ & $\begin{array}{l}\text { Doherty et al. } 2008 \text { [33], } \\
\text { Doherty et al. } 2009 \text { [34], } \\
\text { Keche et al. } 2015 \text { [35], } \\
\text { Mavukwana et al. 2013 } \\
\text { [36], Rupesh et al. } 2016 \\
\text { [37], Dahmani et al. } 2017 \\
\text { [38], Deng et al. } 2017 \text { [39], } \\
\text { Nikoo and Mahinpey 2008 } \\
\text { [40], Panda } 2012 \text { [41], } \\
\text { Peters et al. } 2017 \text { [42], } \\
\text { Kaushal and Tyagi 2017 } \\
\text { [43], Abdelouahed et al. } \\
\text { 2012 [44], Mathieu and } \\
\text { Dubuisson 2002 [45] }\end{array}$ \\
\hline
\end{tabular}

\subsubsection{Model Description}

Figure 1 shows the flow chart of waste biomass gasification simulation by using ASPEN Plus based on the stoichiometric approach and Table 3 gives the brief descriptions of the unit operations of the blocks used in the simulation. The BIOMSS stream was defined as a nonconventional stream and it was created by inputting of elemental and gross compositions of wastes feedstocks obtained from proximate and elemental analyses. The information used to describe the feedstocks is given in Table 4. In the next step, RYIELD, the ASPEN Plus yield reactor, was used to simulate the decomposition of the feed. In pyrolysis/decomposition stage, the feedstock was transformed from a non-conventional solid to volatile materials and char. The volatiles included carbon, hydrogen, oxygen and nitrogen and the char was converted into ash and carbon, by specifying the product distribution based on the proximate and ultimate analysis of the waste biomasses. The yield of volatiles was equal to the volatile content in the fuel according to the proximate analysis [28] [31] [40]. For stoichiometric equilibrium simulation of the combustion and gasification parts, REquil reactor was used in which homogeneous and heterogeneous reactions can be defined, simultaneously. However, due to the limitation of ASPEN Plus that each REquil can only contain one heterogeneous reaction, 4 REquil reactors (RE1-RE4) were considered for 4 heterogeneous reactions of R1, R2, R4, R5 (based on Table 1). Two FSplit blocks were used for dividing of volatiles and air streams among reactors of RE1, RE2 and RE3. Then two Mixer blocks were applied to mix outlet gasses and unburned carbons from the up and bottom of reactors, respectively; the product streams called OUTGAS and CARBON, respectively. Then, OUTGAS and CARBON streams with the rest of air stream were entered to RE4 for the heterogeneous reaction of R5 and homogenous reaction of R7. Eventually, the product gas called SYNGAS was exited from the up of RE4. 
Table 3. Description of ASPEN Plus unit operation blocks used in model.

\begin{tabular}{lll}
\hline $\begin{array}{l}\text { ASPEN } \\
\text { Plus name }\end{array}$ & Block name & Description \\
\hline Ryield & PYROL & $\begin{array}{l}\text { Decomposition of non-conventional biomass to } \\
\text { conventional components according to its proximate } \\
\text { and ultimate analyses. }\end{array}$ \\
Requil & RE1, RE2, RE3, RE4 & $\begin{array}{l}\text { Rigorous equilibrium reactor based on stoichiometric } \\
\text { approach. }\end{array}$ \\
Sep & SEPRATOR & Gas separation from ash by specifying split fractions. \\
FSplit & S1, S2 & $\begin{array}{l}\text { Dividing of gas stream and air stream based on split fractions } \\
\text { by S1 and S2, respectively. }\end{array}$ \\
Mixer & M1, M2 & $\begin{array}{l}\text { Blending of gasses and carbons into one stream by M1 and M2, } \\
\text { respectively. }\end{array}$ \\
\hline
\end{tabular}

Table 4. Ultimate and proximate analysis feedstocks.

\begin{tabular}{cccc}
\hline Feedstocks & Sawdust & Wood chip & Mixed paper waste \\
\hline $\begin{array}{c}\text { Proximate analysis } \\
\text { Proximate analysis (wt) }\end{array}$ & & & \\
Moisture & 7 & 20 & 8.8 \\
Volatile matter (VM) & 81.72 & 80 & 84.2 \\
Fixed carbon (FC) & 17.2 & 18.84 & 7.5 \\
Ash & 1.08 & 1.16 & 8.3 \\
Ultimate analysis & & & \\
Elemental analysis & & & \\
(wt\%-dry basis) & & & 47.96 \\
C & 46.46 & 51.19 & 6.60 \\
H & 5.82 & 6.08 & 0.18 \\
N & 0.19 & 0.2 & 36.96 \\
O & 46.45 & 41.37 & \\
\hline
\end{tabular}

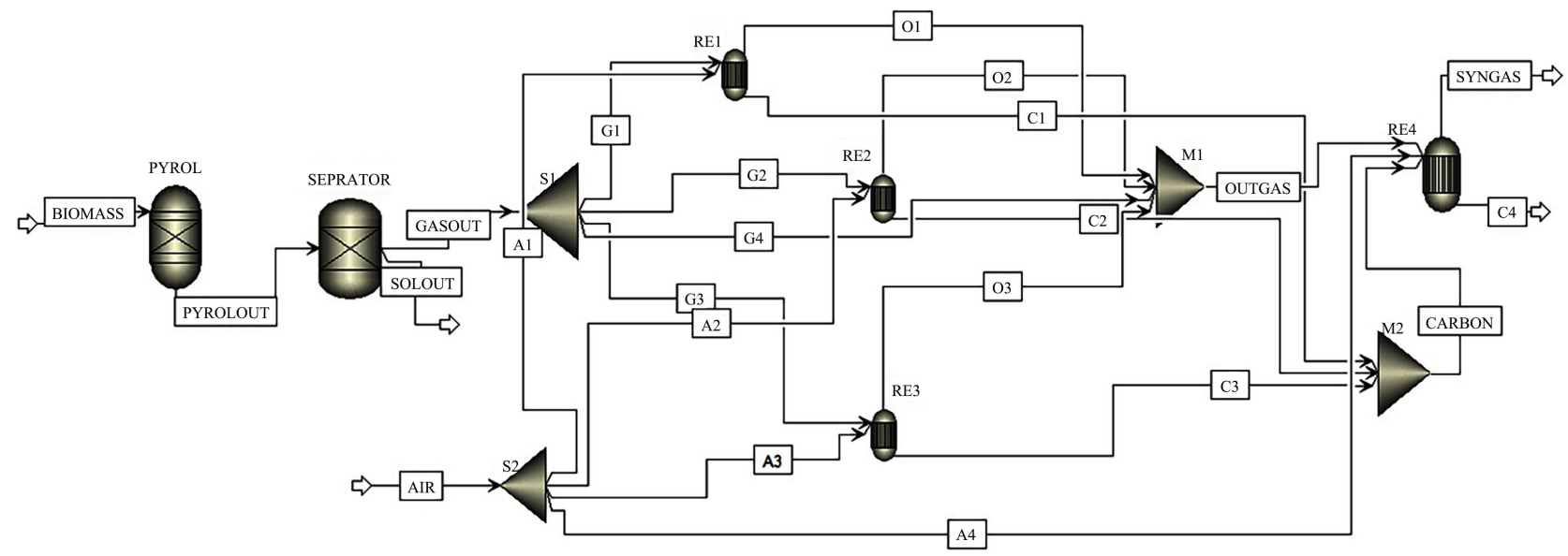

Figure 1. Flow chart of waste biomass gasification simulation using Aspen Plus. 


\section{Validation}

In order to validate the present model, the syngas composition obtained through gasification from the developed simulation model have been compared with the experimental data published by Jayah (2002) [46] and with the thermodynamic analyses based on non-stoichiometric of Paviet et al. (2009) [17]. They conducted air gasification of rubber wood as biomass feedstock in a down draft gasifier. Figure 2 shows the results of comparison at temperature of $1300 \mathrm{~K}$ and air to fuel ratio of 2.53. It can be observed that the present model shows better agreement with the experimental results compared to the non-stoichiometric based model. Only formation of methane was underestimated by the model which is quite a common problem for equilibrium models that cannot predict much more hydrocarbons (especially methane) [17] [24] [34].

The stoichiometric thermodynamic model of gasification was also validated by comparing the current predictions to the experimental results of Jayah et al. [47]. In their work, rubber wood was considered as feedstock into a down draft gasifier operated at atmospheric pressure and the gasification temperature of $900^{\circ} \mathrm{C}$. Six different air to fuel mass flow rate ratios (AFRs) were considered and the comparisons of $\mathrm{CO}, \mathrm{H}_{2}, \mathrm{CO}_{2}$ and $\mathrm{N}_{2}$ concentrations were shown in Figure 3 . The deviation of the model results from experimental values is quantified by using statistical parameter RMS (root mean square) error. The maximum RMS error of 1.89 is obtained when six sets of experimental data are compared with the corresponding model values for syngas composition.

\section{Results and Discussion}

In this study, the developed model for waste biomass gasification has been used to investigate the gasification performance of three different waste feedstocks: sawdust, wood chips and mixed paper waste. The effect of gasifier temperature and equivalence ration (ER) on syngas composition, syngas yield, lower heating value (LHV) of produced gas and cold gas efficiency (CGE) has been investigated. Syngas yield in this model is the volume of total product gas from the gasification per unit weight of fuel in normal conditions $\left(\mathrm{Nm}^{3} \mathrm{~kg}_{\text {fuel }}{ }^{-1}\right)$. The lower heating value of product gas is calculated as [28] [48]:

$$
\operatorname{LHV}_{\text {syngas }}\left(\mathrm{kj} / \mathrm{Nm}^{3}\right)=4.2 \times\left(30 \times y_{C O}+25.7 \times y_{H_{2}}+85.4 \times y_{C_{4}}\right)
$$

where $y$ is the mole fraction of gas pieces in the syngas (dry basis).

The cold gas efficiency (CGE) is an important index to account for the performance of biomass gasification that it is calculated by using Equation (2) [28] [49]:

$$
\operatorname{CGE}(\%)=\frac{\mathrm{G}_{\mathrm{P}} \times \mathrm{LHV}_{\text {syngas }}}{\mathrm{HHV}_{\text {fuel }}} \times 100
$$

where GP is the syngas yield and $\mathrm{HHV}_{\text {fuel }}$ is the higher heating value of fuel (M) $\mathrm{kg} \mathrm{fuel}^{-1}$ ) that it is calculated by below equation [50]. 


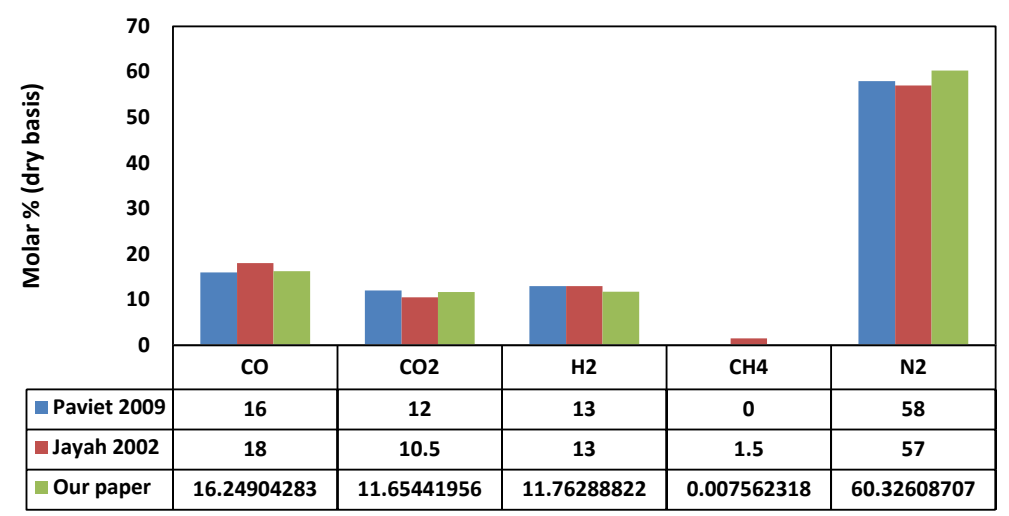

Figure 2. Comparisons of syngas composition between our model and Jayah (2002) [46] experimental measurements and Paviet et al. (2009) [17] model.

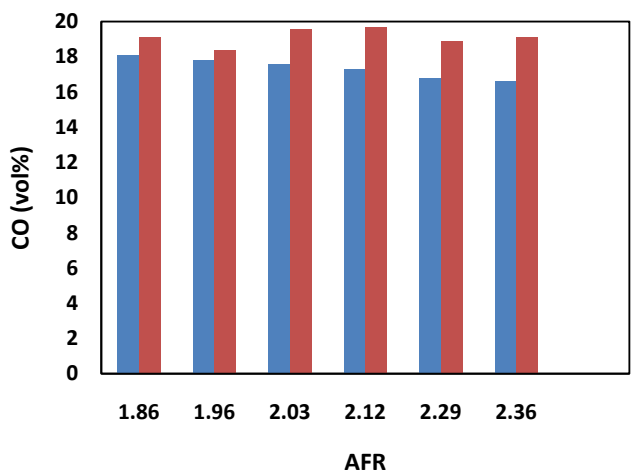

(a)

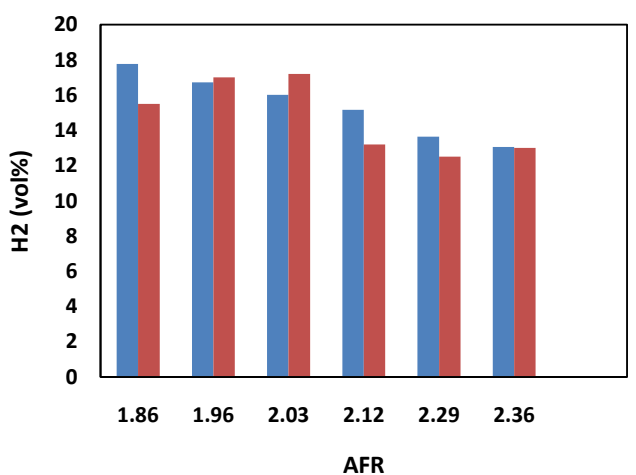

(b)

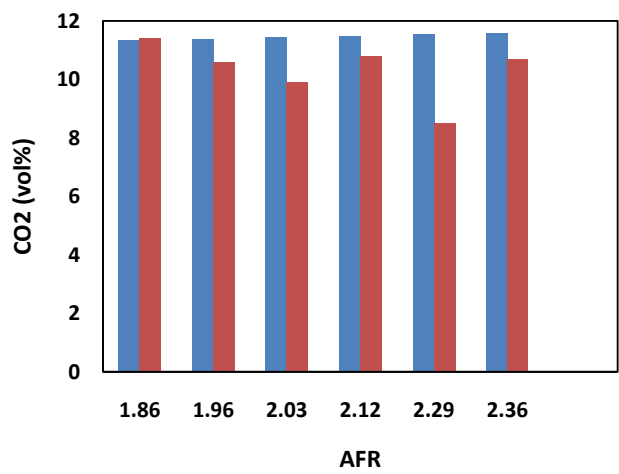

(c)
CO (Our paper)

n CO (Jayah)

- H2 (Our paper)

- H2 (Jayah)

CO2 (Our paper)

- $\mathrm{CO} 2$ (Jayah) 


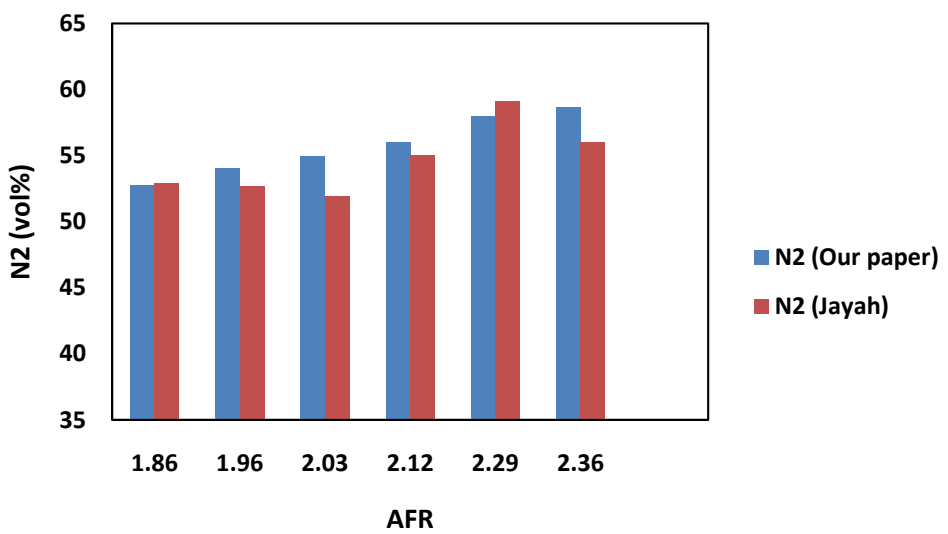

(d)

Figure 3. Comparisons of (a) $\mathrm{CO}$, (b) $\mathrm{H}_{2}$, (c) $\mathrm{CO}_{2}$ and (d) $\mathrm{N}_{2}$ concentrations between stoichiometric predictions and experimental measurements.

$$
\operatorname{HHV}_{\text {fuel }}(\mathrm{Mj} / \mathrm{kg})=0.312 \times(\mathrm{FC})+0.1534 \times(\mathrm{VM})
$$

According to the Equation (3), heating value is a function of weight fractions of fixed carbon and volatile matter in the dry and ash-free conditions.

\subsection{Effect of Temperature on Syngas Composition}

The effect of gasifier temperature on syngas mole fractions for three feedstocks was examined in the window of $500^{\circ} \mathrm{C}-1500^{\circ} \mathrm{C}$, while all the remaining operating conditions were fixed. As shown in Figure 4, at very low temperature of $500^{\circ} \mathrm{C}$ the existing carbon in the biomass is not used completely, so the syngas production would not be in a good rate. In such a low temperature, unburned carbon and methane will remain in syngas while by increasing temperature more carbon is oxidized and converted to carbon monoxide in accordance with partial combustion reaction (R2). Methane is also transferred into hydrogen by reverse methanation reaction (R5). Moreover, at high temperature, water gas reaction (R4) goes toward the production of both carbon monoxide and hydrogen. Hence, increasing the gasifier temperature favors hydrogen and carbon monoxide production, leads to the improvement of heating value of syngas (based on Equation (1)). However, at a specific temperature, yield of $\mathrm{H}_{2}$ and $\mathrm{CO}$ reach to an approximately fixed points that this point can be the optimum gasifier temperature for each waste. The optimum operating temperature of the down draft gasifier for sawdust, wood chips and paper wastes are $900^{\circ} \mathrm{C}, 1000^{\circ} \mathrm{C}$ and $1000^{\circ} \mathrm{C}$, respectively. Methane production also decreases sharply at temperatures above $600^{\circ} \mathrm{C}$ for three wastes. For both sawdust and wood chips wastes, mole fraction of $\mathrm{CO}$ is higher than $\mathrm{H}_{2}$ mole fraction but general behavior is not the same for paper waste. According to the elemental analysis of feedstocks, mixed paper waste has the highest hydrogen and the lowest oxygen among the others, consequently the product gas from paper gasification includes lower $\mathrm{CO}$ but higher $\mathrm{H}_{2}$ in comparison other wastes. 


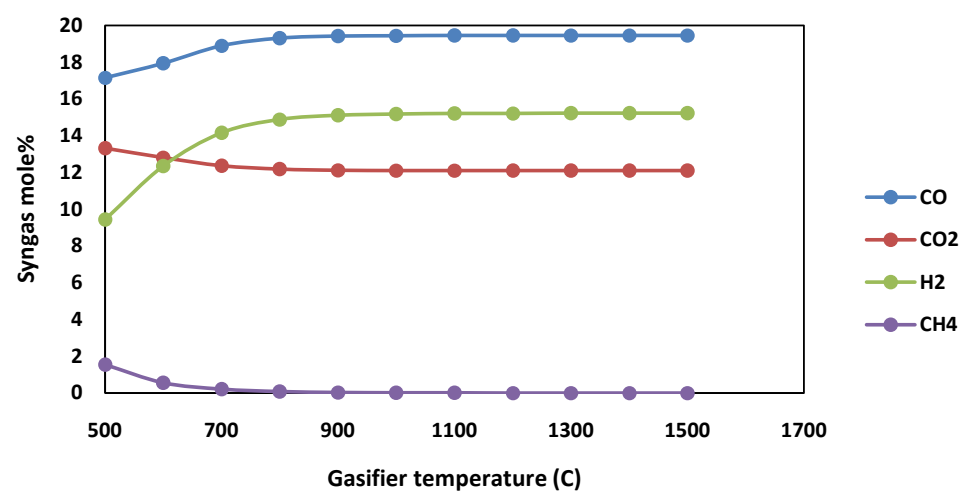

(a)

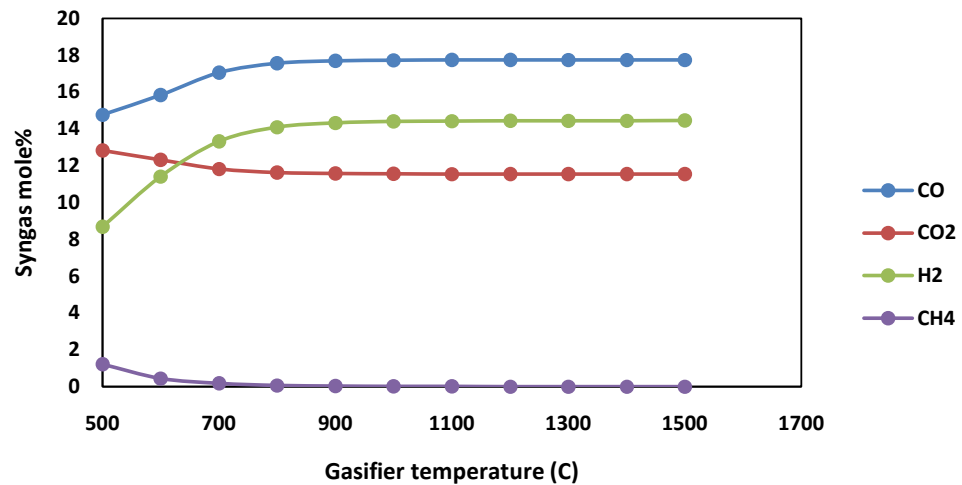

(b)

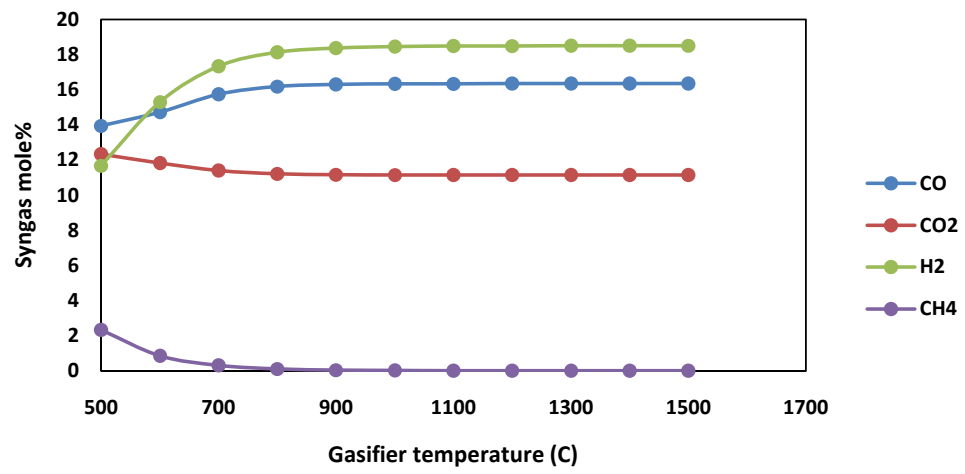

(c)

Figure 4. Effect of temperature on syngas mole fraction (dry basis), (a) sawdust, (b) wood chip, (c) mixed paper waste.

\subsection{Effect of ER on Syngas Composition}

Equivalence Ratio (ER) is an important index for showing the role of oxidizing agent and it is defined as the ratio of the amount of actual air supplied to the gasifier to the stoichiometric air. At low ER, biomass reactions will approach to the pyrolysis, whereas at a high ER the excess amount of oxygen oxidizes the fuel completely and causes biomass combustion; then the production of syngas declines. Hence, it is important to find the appropriate range of ER for biomass gasification that has been studied in this work. In this case, the ER in the gasifier was varied from $0.1-0.7$ and its influence on the syngas compositions were 
shown in Figure 5 for three wastes. The $\mathrm{H}_{2}$ mole fraction decreases with increasing ER, regardless of which biomass is used as the feedstock. Similar to $\mathrm{H}_{2}$ formation, the mole fraction of $\mathrm{CO}$ also decreases with increasing ER but an opposite trend for $\mathrm{CO}_{2}$ is exhibited. This is due to when ER rises, more oxygen is supplied for biomass reactions, so fuel goes toward the full combustion. Sawdust has highest mole fraction of carbon monoxide and hydrogen in syngas $(0.28$ and 0.38 , respectively). Conversely, the gasification of mixed paper waste gives the lowest mole fraction of CO (0.22). Finally, as shown in Figure 5 the optimum ER lies between 0.2 - 0.35 for three wastes (till mole fractions of carbon monoxide and hydrogen are higher than $20 \%$ ).

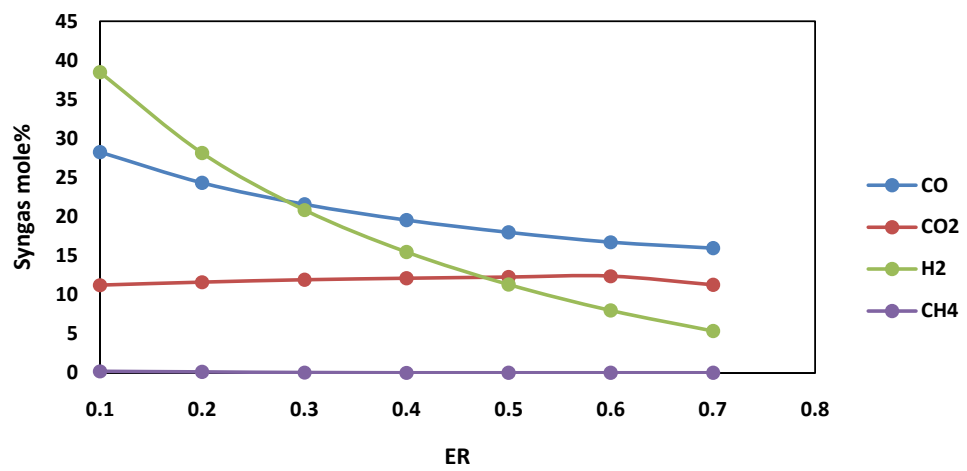

(a)

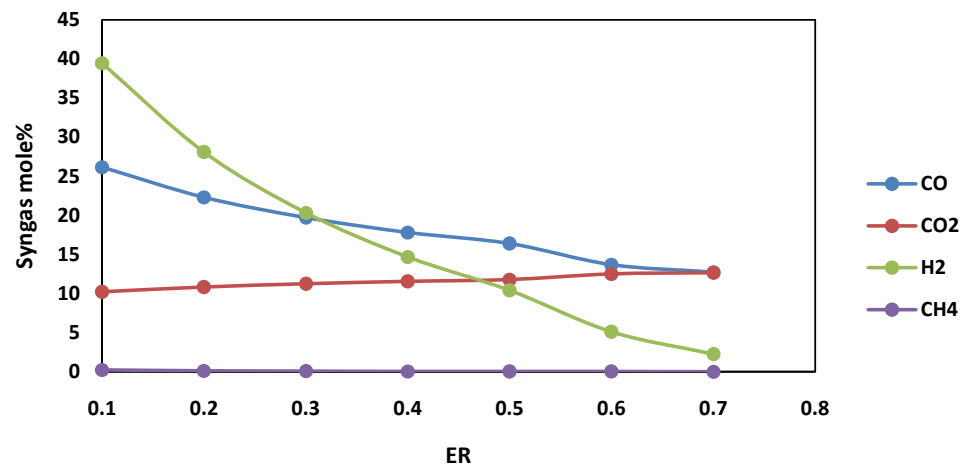

(b)

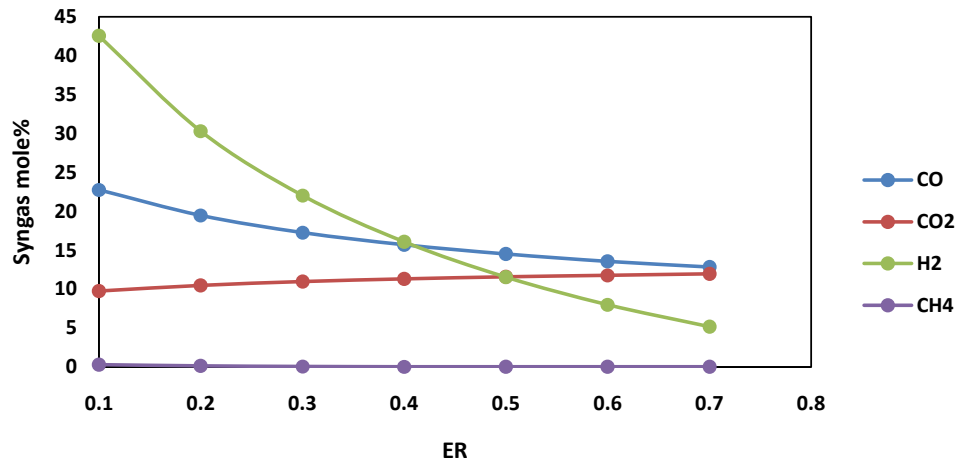

(c)

Figure 5. Effect of ER on syngas mole fraction (dry basis), (a) sawdust, (b) wood chip, (c) mixed paper waste. 


\subsection{Effect of Temperature and ER on Syngas Yield}

The effect of the gasifier temperature on the syngas yield is illustrated on Figure $6(\mathrm{a})$. When the operating temperature of gasifier is increased from $500^{\circ} \mathrm{C}$ $900^{\circ} \mathrm{C}$, the syngas yield is increased $4.6 \%$ for sawdust and wood chips and $5.4 \%$ for mixed paper waste and then reach to approximately fixed points. It can be explained by increasing gasifier temperature, the unburned carbon is converted into carbon monoxide and through the reverse methanation reaction, methane is converted into hydrogen. Finally, mole fractions of components attain to the constant amounts that cause nearly constant values for syngas yield. Figure 6(a) depicts that the syngas yield for wood chips gasification is higher than other wastes, because syngas production from gasification of wood chips waste has highest carbon monoxide and hydrogen due to high percentage of carbon and hydrogen in wood chips biomass (as shown in Table 4).

The variation of syngas yield for three wastes by varying ER is shown in Figure $6(\mathrm{~b})$. The syngas yield from the gasification of paper waste is higher than that of wood chip and sawdust wastes averagely 7.3\%. As ER increases from 0.1 to 0.7 , syngas yield continuously increases because more oxygen is available for biomass reactions at high ER but so high syngas yield does not mean high gasification performance. Because as it was explained in Section 4.2, with access to more oxygen, the fuel is oxidized completely and causes biomass combustion; then the production of $\mathrm{CO}$ and $\mathrm{H}_{2}$ decline and $\mathrm{CO}_{2}$ production increases. In the optimum range of ER, syngas yield values for sawdust, wood chips and paper wastes are in the span of $2.08-3.00 \mathrm{Nm}^{3} \mathrm{~kg}_{\text {fuel }}{ }^{-1}$.

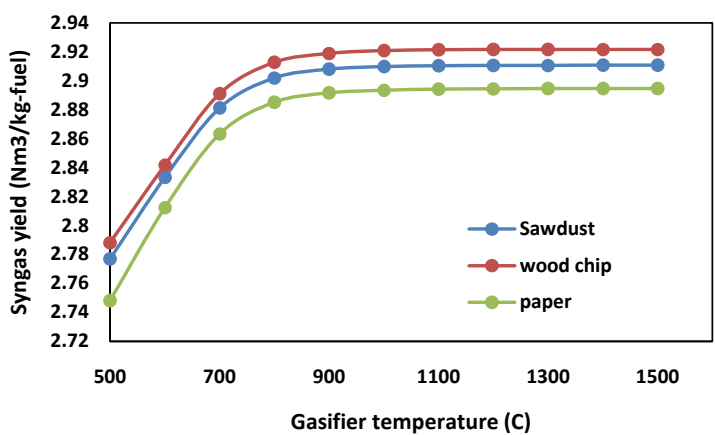

(a)

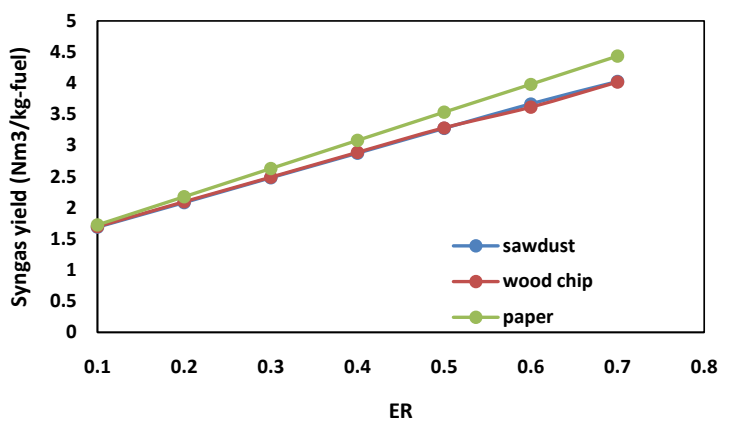

(b)

Figure 6. (a) Effect of temperature on syngas yield; (b) Effect of ER on syngas yield. 


\subsection{Effect of Temperature and ER on LHV}

Figure 7(a) shows the lower heating value of syngas as a function of temperature. The increase in temperature of the gasification zone at fixed AFR of 2.03 results in an increase in the LHV of the syngas till a specific temperature that is called optimum temperature. LHV values for sawdust, wood chips and mixed paper wastes at optimum temperatures $\left(900^{\circ} \mathrm{C}, 1000^{\circ} \mathrm{C}\right.$ and $1100^{\circ} \mathrm{C}$, respectively) are about 4.09, 3.79 and $4.06 \mathrm{Mj} \cdot \mathrm{Nm}^{-3}$, respectively. Wood chip shows lowest heating value among the three wastes due to relatively lower dry basis mole fraction of carbon monoxide and hydrogen in the syngas. The production of carbon monoxide and hydrogen is dependent on the biomass composition and it is clear from the composition of feedstocks provided in Table 4 that although wood chip has highest percentage of carbon, it includes so high amount of moisture. Moisture content indirectly effects on LHV of syngas. Increasing moisture content strongly degrades the syngas LHV. As a consequence of much higher moisture content in the fuel, the percentage of carbon and hydrogen in wet basis decrease then leads to lower production of carbon monoxide and hydrogen in the syngas.

The sensitivity of ER over the LHV of the product syngas at the fixed gasifier temperature of $900^{\circ} \mathrm{C}$ for three waste biomasses is shown in Figure $7(\mathrm{~b})$. By

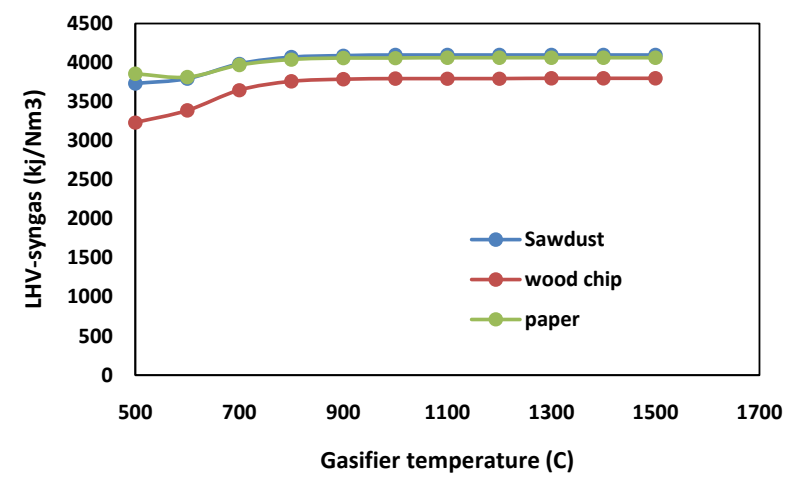

(a)

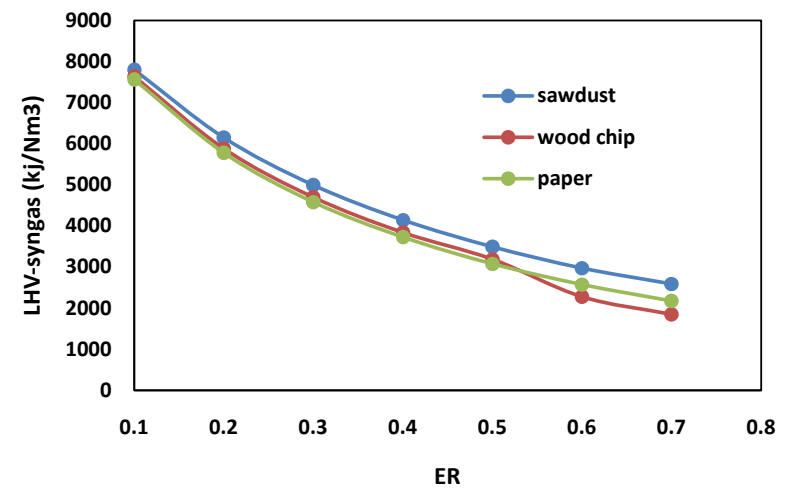

(b)

Figure 7. (a) Effect of temperature on syngas LHV; (b) Effect of ER on syngas LHV. 
increasing ER, the production of carbon monoxide and hydrogen in syngas decrease due to complete combustion of fuel, so the heating value of the syngas decreases. As a whole, the LHV of the product gas depends strongly on ER and it is in the range of 4.15 and $6.147 \mathrm{MJ} \cdot \mathrm{Nm}^{-3}$ In the optimum range of ER. On the other hand, the effect of feedstock on LHV is slight.

\subsection{Effect of Temperature and ER on CGE}

Cold gas efficiency is the most crucial parameter that practically indicates the economic efficiency of the gasifier. Accordance to Equation (2), CGE is dependent on different parameters of syngas yield, HHV of fuel and LHV of syngas, but it eventually depends on the amount of carbon monoxide, hydrogen and methane in the product syngas. The composition of syngas is also controlled by temperature and ER hence they are the important parameters for evaluating of CGE. In our model temperature has been varied from $500^{\circ} \mathrm{C}-1500{ }^{\circ} \mathrm{C}$ and the corresponding CGE is calculated. The results have been depicted in Figure 8(a). Mixed paper waste shows highest CGE (70.6\%) at temperature of $1000^{\circ} \mathrm{C}$ while for sawdust CGE is maximum around $65,8 \%$ and wood chips shows lowest CGE (60\%) among the three wastes. Figure 8(b) shows that increasing ER reduces the value of CGE, stemming from the reduction of LHV (Figure 7(b)). For the three waste biomasses, the amount of CGE is under $60 \%$ as long as ER is more than 0.4. It follows that ER should be controlled below 0.4.

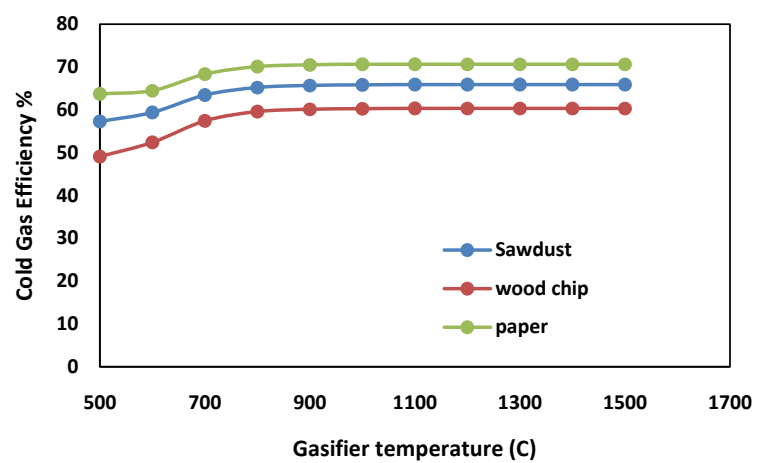

(a)

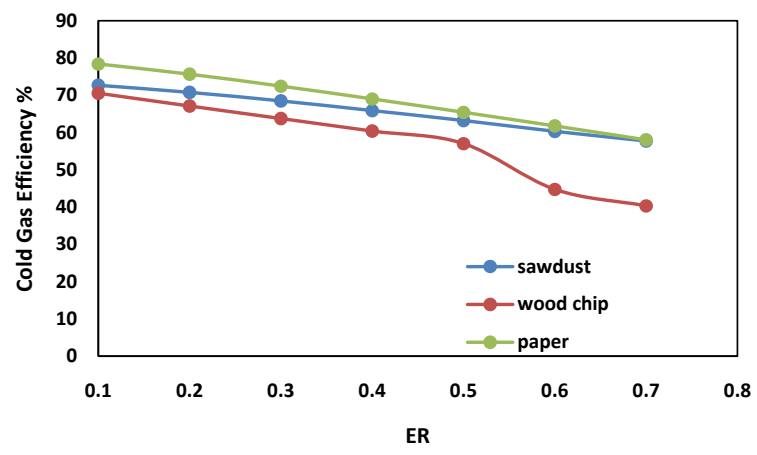

(b)

Figure 8. (a) Effect of temperature on CGE; (b) Effect of ER on CGE. 


\section{Conclusions}

A new steady state stoichiometric equilibrium-based model was developed for waste biomass gasification using ASPEN Plus simulator. Prediction accuracy of the model was checked by comparing with available experimental and modeling results in other researches. Then the model was used for comparative analysis of the gasification performance of sawdust, wood chips and mixed paper wastes. In the model, sensitivity analysis was performed and the impact of varying gasifier operating temperature and ER on syngas composition, syngas yield, HHV of syngas and CGE was investigated. Raise in temperature improves the gasifier performance, it increases the production of $\mathrm{CO}$ and $\mathrm{H}_{2}$ which leads to higher syngas yield, LHV and CGE. However, increasing ER lessens the production of $\mathrm{CO}$ and $\mathrm{H}_{2}$ which results in reduction of gasification performance. The optimal values of $\mathrm{CO}$ and $\mathrm{H}_{2}$ mole fraction and CGE of sawdust, wood chips and mixed paper wastes are located at $900^{\circ} \mathrm{C}, 1000^{\circ} \mathrm{C}$ and $1000^{\circ} \mathrm{C}$, respectively and $\mathrm{ER}$ range is between $0.20-0.35$ regardless of the kind of biomass which is used as the feedstock. Among the three wastes considered, sawdust shows the highest CO mole fraction and LHV in the product syngas. Although, wood chips waste has the highest carbon percent among the other wastes, it has slight carbon yield, low CO mole fraction as well as lowest LHV. It is due to that it includes so high amount of moisture and moisture content indirectly effects on LHV of syngas, increasing moisture content strongly degrades the syngas LHV. Moreover, mixed paper waste shows the highest CGE $(70.6 \%)$ at temperature of $1000^{\circ} \mathrm{C}$ due to so high hydrogen content and the low HHV of its feedstock while for sawdust CGE is maximum around $65.8 \%$ and wood chips show lowest CGE (60\%) among the three wastes.

Further works are required to evaluate the effects of moisture content on the gasification performance and to study the integrated gasifier with CHP to investigate the impact of operating parameters on power production.

\section{Acknowledgements}

This paper was a part of the project funded by Icelandic Research Fund (IRF), (in Icelandic: Rannsoknasjodur) and the grant number is 196458-051.

\section{Conflicts of Interest}

The authors declare no conflicts of interest regarding the publication of this paper.

\section{References}

[1] Rajaeifar, M.A., Akram, A., Ghobadian, B., Rafiee, S., Heijungs, R. and Tabatabaei, M. (2016) Environmental Impact Assessment of Olive Pomace Oil Biodiesel Production and Consumption: A Comparative Lifecycle Assessment. Energy, 106, 87-102. https://doi.org/10.1016/j.energy.2016.03.010

[2] Safarian, S., Khodaparast, P. and Kateb, M. (2014) Modeling and Technical-Economic Optimization of Electricity Supply Network by Three Photovoltaic Systems. Journal 
of Solar Energy Engineering, 136, Article ID: 024501. https://doi.org/10.1115/1.4025120

[3] Safarian, S. and Unnthorsson, R. (2018) An Assessment of the Sustainability of Lignocellulosic Bioethanol Production from Wastes in Iceland. Energies, 11, 1493. https://doi.org/10.3390/en11061493

[4] Safarian, S., Sattari, S. and Hamidzadeh, Z. (2018) Sustainability Assessment of Biodiesel Supply Chain from Various Biomasses and Conversion Technologies. Biophysical Economics and Resource Quality, 3, 6. https://doi.org/10.1007/s41247-018-0039-2

[5] Safarian, S., Sattari, S., Unnthorsson, R. and Hamidzadeh, Z. (2019) Prioritization of Bioethanol Production Systems from Agricultural and Waste Agricultural Biomass Using Multi-Criteria Decision Making. Biophysical Economics and Resource Quality, 4, 1-16. https://doi.org/10.1007/s41247-019-0052-0

[6] Formica, M., Frigo, S. and Gabbrielli, R. (2016) Development of a New Steady State Zero-Dimensional Simulation Model for Woody Biomass Gasification in a Full Scale Plant. Energy Conversion and Management, 120, 358-369.

https://doi.org/10.1016/j.enconman.2016.05.009

[7] Arena, U. (2012) Process and Technological Aspects of Municipal Solid Waste Gasification. A Review. Waste Management, 32, 625-639.

https://doi.org/10.1016/j.wasman.2011.09.025

[8] Münster, M. and Lund, H. (2010) Comparing Waste-to-Energy Technologies by Applying Energy System Analysis. Waste Management, 30, 1251-1263.

https://doi.org/10.1016/j.wasman.2009.07.001

[9] Murphy, J.D. and McKeogh, E. (2004) Technical, Economic and Environmental Analysis of Energy Production from Municipal Solid Waste. Renewable Energy, 29, 1043-1057. https://doi.org/10.1016/j.renene.2003.12.002

[10] Kasembe, E.D., Mganilwa, Z.M., Mganilwa, Z.M., John, G.R. and Mhilu, C.F. (2015) Syngas Production and Losses Encountered in Gasification of Rice Husks. Journal of Power and Energy Engineering, 3, 423. https://doi.org/10.4236/jpee.2015.34057

[11] Safarian, S., Unnpórsson, R. and Richter, C. (2019) A Review of Biomass Gasification Modelling. Renewable and Sustainable Energy Reviews, 110, 378-391. https://doi.org/10.1016/j.rser.2019.05.003

[12] Basu, P. (2006) Combustion and Gasification in Fluidized Beds. CRC Press, Boca Raton. https://doi.org/10.1201/9781420005158

[13] Kivisaari, T., Björnbom, P., Sylwan, C., Jacquinot, B., Jansen, D. and de Groot, A. (2004) The Feasibility of a Coal Gasifier Combined with a High-Temperature Fuel Cell. Chemical Engineering Journal, 100, 167-180. https://doi.org/10.1016/j.cej.2003.12.005

[14] Boerrigter, H. and Rauch, R. (2006) Review of Applications of Gases from Biomass Gasification. ECN Biomassa, Kolen en Milieuonderzoek, 20.

[15] Puig-Arnavat, M., Bruno, J.C. and Coronas, A. (2010) Review and Analysis of Biomass Gasification Models. Renewable and Sustainable Energy Reviews, 14, 2841-2851. https://doi.org/10.1016/j.rser.2010.07.030

[16] Baratieri, M., Pieratti, E., Nordgreen, T. and Grigiante, M. (2010) Biomass Gasification with Dolomite as Catalyst in a Small Fluidized Bed Experimental and Modelling Analysis. Waste and Biomass Valorization, 1, 283-291. https://doi.org/10.1007/s12649-010-9034-6

[17] Paviet, F., Chazarenc, F. and Tazerout, M. (2009) Thermo Chemical Equilibrium 
Modeling of a Biomass Gasifying Process Using Aspen Plus. International Journal of Chemical Reactor Engineering, 7.

https://doi.org/10.2202/1542-6580.2089

[18] Begum, S., Rasul, M. and Akbar, D. (2014) A Numerical Investigation of Municipal Solid Waste Gasification Using Aspen Plus. Procedia Engineering, 90, 710-717. https://doi.org/10.1016/j.proeng.2014.11.800

[19] Pardo-Planas, O., Atiyeh, H.K., Phillips, J.R., Aichele, C.P. and Mohammad, S. (2017) Process Simulation of Ethanol Production from Biomass Gasification and Syngas Fermentation. Bioresource Technology, 245, 925-932. https://doi.org/10.1016/j.biortech.2017.08.193

[20] Eikeland, M.S., Thapa, R. and Halvorsen, B. (2015) Aspen Plus Simulation of Biomass Gasification with Known Reaction Kinetic. Proceedings of the 56 th Conference on Simulation and Modeling, Linköping, 7-9 October 2015, 149-156. https://doi.org/10.3384/ecp15119149

[21] Eikeland, M.S. and Thapa, R.K. (2017) Stepwise Analysis of Gasification Reactions with Aspen Plus and CPFD. International Journal of Energy Production and Management, 2, 70-80. https://doi.org/10.2495/EQ-V2-N1-70-80

[22] Guruprasad, R., Renganathan, T. and Pushpavanam, S. (2014) Generalized Thermodynamic Analysis of High Pressure Air Blown Gasifier. Industrial and Engineering Chemistry Research, 53, 18750-18760. https://doi.org/10.1021/ie500898y

[23] Ramzan, N., Ashraf, A., Naveed, S. and Malik, A. (2011) Simulation of Hybrid Biomass Gasification Using Aspen Plus: A Comparative Performance Analysis for Food, Municipal Solid and Poultry Waste. Biomass and Bioenergy, 35, 3962-3969. https://doi.org/10.1016/j.biombioe.2011.06.005

[24] Pala, L.P.R., Wang, Q., Kolb, G. and Hessel, V. (2017) Steam Gasification of Biomass with Subsequent Syngas Adjustment Using Shift Reaction for Syngas Production: An Aspen Plus Model. Renewable Energy, 101, 484-492.

https://doi.org/10.1016/j.renene.2016.08.069

[25] Sun, K. (2015) Optimization of Biomass Gasification Reactor Using Aspen Plus. Høgskolen i Telemark, Porsgrunn.

[26] Fernandez-Lopez, M., Pedroche, J., Valverde, J. and Sanchez-Silva, L. (2017) Simulation of the Gasification of Animal Wastes in a Dual Gasifier Using Aspen Plus ${ }^{\circledast}$. Energy Conversion and Management, 140, 211-217. https://doi.org/10.1016/j.enconman.2017.03.008

[27] Kong, X., et al. (2013) Three Stage Equilibrium Model for Coal Gasification in Entrained Flow Gasifiers Based on Aspen Plus. Chinese Journal of Chemical Engineering, 21, 79-84. https://doi.org/10.1016/S1004-9541(13)60444-9

[28] Kuo, P.-C., Wu, W. and Chen, W.-H. (2014) Gasification Performances of Raw and Torrefied Biomass in a Downdraft Fixed Bed Gasifier Using Thermodynamic Analysis. Fuel, 117, 1231-1241. https://doi.org/10.1016/j.fuel.2013.07.125

[29] Gagliano, A., Nocera, F., Bruno, M. and Cardillo, G. (2017) Development of an Equilibrium-Based Model of Gasification of Biomass by Aspen Plus. Energy Procedia, 111, 1010-1019. https://doi.org/10.1016/j.egypro.2017.03.264

[30] Lestinsky, P. and Palit, A. (2016) Wood Pyrolysis Using Aspen Plus Simulation and Industrially Applicable Model. GeoScience Engineering, 62, 11-16. https://doi.org/10.1515/gse-2016-0003

[31] Damartzis, T., Michailos, S. and Zabaniotou, A. (2012) Energetic Assessment of a Combined Heat and Power Integrated Biomass Gasification-Internal Combustion Engine System by Using Aspen Plus ${ }^{\circledast}$. Fuel Processing Technology, 95, 37-44. 
https://doi.org/10.1016/j.fuproc.2011.11.010

[32] Han, J., Liang, Y., Hu, J., Qin, L., Street, J., Lu, Y. and Yu, F. (2017) Modeling Downdraft Biomass Gasification Process by Restricting Chemical Reaction Equilibrium with Aspen Plus. Energy Conversion and Management, 153, 641-648. https://doi.org/10.1016/j.enconman.2017.10.030

[33] Doherty, W., Reynolds, A. and Kennedy, D. (2008) Simulation of a Circulating Fluidised Bed Biomass Gasifier Using Aspen Plus: A Performance Analysis.

[34] Doherty, W., Reynolds, A. and Kennedy, D. (2009) The Effect of Air Preheating in a Biomass CFB Gasifier Using Aspen Plus Simulation. Biomass and Bioenergy, 33, 1158-1167. https://doi.org/10.1016/j.biombioe.2009.05.004

[35] Keche, A.J., Gaddale, A.P.R. and Tated, R.G. (2015) Simulation of Biomass Gasification in Downdraft Gasifier for Different Biomass Fuels Using Aspen Plus. Clean Technologies and Environmental Policy, 17, 465-473. https://doi.org/10.1007/s10098-014-0804-X

[36] Mavukwana, A., Jalama, K., Ntuli, F. and Harding, K. (2013) Simulation of Sugarcane Bagasse Gasification Using Aspen Plus. International Conference on Chemical and Environmental Engineering, Johannesburg, 15-16 April 2013, 70-74.

[37] Rupesh, S., Muraleedharan, C. and Arun, P. (2016) Aspen Plus Modeling of Air-Steam Gasification of Biomass with Sorbent Enabled $\mathrm{CO}_{2}$ Capture. Resource-Efficient Technologies, 2, 94-103. https://doi.org/10.1016/j.reffit.2016.07.002

[38] Dahmani, M., Périlhon, C., Marvillet, C., Hajjaji, N., Houas, A. and Khila, Z. (2017) Development of a Fixed Bed Gasifier Model and Optimal Operating Conditions Determination. AIP Conference Proceedings, 1814, Article ID: 020069. https://doi.org/10.1063/1.4976288

[39] Deng, N., Zhang, A., Zhang, Q., He, G., Cui, W., Chen, G. and Song, C. (2017) Simulation Analysis and Ternary Diagram of Municipal Solid Waste Pyrolysis and Gasification Based on the Equilibrium Model. Bioresource Technology, 235, 371-379. https://doi.org/10.1016/j.biortech.2017.03.072

[40] Nikoo, M.B. and Mahinpey, N. (2008) Simulation of Biomass Gasification in Fluidized Bed Reactor Using Aspen Plus. Biomass and Bioenergy, 32, 1245-1254. https://doi.org/10.1016/j.biombioe.2008.02.020

[41] Panda, C. (2012) Aspen Plus Simulation and Experimental Studies on Biomass Gasification.

[42] Peters, J.F., Banks, S.W., Bridgwater, A.V. and Dufour, J. (2017) A Kinetic Reaction Model for Biomass Pyrolysis Processes in Aspen Plus. Applied Energy, 188, 595-603. https://doi.org/10.1016/j.apenergy.2016.12.030

[43] Kaushal, P. and Tyagi, R. (2017) Advanced Simulation of Biomass Gasification in a Fluidized Bed Reactor Using Aspen Plus. Renewable Energy, 101, 629-636. https://doi.org/10.1016/j.renene.2016.09.011

[44] Abdelouahed, L., Authier, O., Mauviel, G., Corriou, J.-P., Verdier, G. and Dufour, A. (2012) Detailed Modeling of Biomass Gasification in Dual Fluidized Bed Reactors under Aspen Plus. Energy and Fuels, 26, 3840-3855. https://doi.org/10.1021/ef300411k

[45] Mathieu, P. and Dubuisson, R. (2002) Performance Analysis of a Biomass Gasifier. Energy Conversion and Management, 43, 1291-1299. https://doi.org/10.1016/S0196-8904(02)00015-8

[46] Jayah, T.H. (2002) Evaluation of a Downdraft Wood Gasifier for Tea Manufacturing in Sri Lanka. Melbourne University, Victoria. 
[47] Jayah, T., Aye, L., Fuller, R.J. and Stewart, D. (2003) Computer Simulation of a Downdraft Wood Gasifier for Tea Drying. Biomass and Bioenergy, 25, 459-469. https://doi.org/10.1016/S0961-9534(03)00037-0

[48] Lv, P., Xiong, Z., Chang, J., Wu, C., Chen, Y. and Zhu, J. (2004) An Experimental Study on Biomass Air-Steam Gasification in a Fluidized Bed. Bioresource Technology, 95, 95-101. https://doi.org/10.1016/j.biortech.2004.02.003

[49] Gai, C. and Dong, Y. (2012) Experimental Study on Non-Woody Biomass Gasification in a Downdraft Gasifier. International Journal of Hydrogen Energy, 37, 4935-4944. https://doi.org/10.1016/j.ijhydene.2011.12.031

[50] Demirbaş, A. (1997) Calculation of Higher Heating Values of Biomass Fuels. Fuel, 76, 431-434. https://doi.org/10.1016/S0016-2361(97)85520-2 